Egyptian Journal of Aquatic Biology \& Fisheries

Zoology Department, Faculty of Science,

Ain Shams University, Cairo, Egypt.

ISSN $1110-6131$

Vol. 23(4): 23 - 37 (2019)

www.ejabf.journals.ekb.eg

\title{
Utilization of Ginger Extract in Nile Tilapia (Oreochromis niloticus) Diets.
}

Saad M. Alsaiad and Ahmed M. Al-Zayat

Faculty of Agriculture, Al-Azhar University, Nasr City, Cairo, Egypt.

\section{ARTICLE INFO \\ Article History: \\ Received: July 8, 2019 \\ Accepted: Sept. 28, 2019 \\ Online: Oct. 2019}

\section{Keywords:}

Nile Tilapia

feed additives

Ginger extract

Growth Performance

Cost benefit

\begin{abstract}
A feeding trial was carried out to study the effect of dietary inclusion of different levels of ginger on growth performance, feed, nutrient utilization, body composition and cost benefit analysis of the Nile tilapia. Nine hapa $\left(3 \times 3 \times 1 \mathrm{~m}^{3}\right)$ were used, each was stocked with 50 fish (overage initial weight $10 \mathrm{~g} / \mathrm{fish})$. Nine experimental diets were formulated to contain $(0.5$ and $10 \%$ of ginger extract protein instead of soybean meal protein). All the diets were isonitrogenous (30\% protein) and isocaloric $(4500 \mathrm{Kcal} / \mathrm{kg})$ diet, gross energy. Fish were fed on the experimental diets at a rate of $5 \%$ of their body weight daily for 16 weeks. The feed amount was given at two times daily. Nile tilapia fed the diet containing $(1 \%)$ ginger extract exhibited the best performance, feed conversion, and protein efficiency ratio compared with the control and level $0.5 \%$ ginger in fish diets. The body composition was not affected by ginger extract up to $0.5 \%$ inclusion level. However, the higher level of ginger inclusion caused high protein and low lipid contents of fish body than the control diet. Cost benefit analysis showed high profil index and low incidence cost with the ginger inclusion in the diets.
\end{abstract}

\section{INTRODUCTION}

Over the last several years, research efforts centered around the application of herbs in the diets have been directed as means of reducing the symptoms of stress acting as a natural growth promoter and improving the general health (Abd Elmonem et al., 2002; Shalaby et al., 2003 and El-Dakar et al., 2004). Medicinal and aromatic plants have been used for many years in human nutrition as a spices and medical additives for animals to increase dietary energy utilization, improve the performance efficiency and as a new source of protein (El-Katcha, 1990 and Abdel-Aal and Attia, 1993). Nowadays, there is an increased demand for using medical plants in therapy instead of using synthetic drugs (Hussein et al., 2000; Abdelhamid et al., 2002, 2003a and 2004 b-e and Abdelhamid, 2003a), which have many adverse effects. Black seed meal (Nigella sativa) and Ginger are used by Egyptian people as diuretic, carminative and flavoring agent for bread (El-Alfy and Atoama, 1975). The seeds are used for their antibacterial, antifungal, and protective action against hepatotoxicity and cirrhosis (Agarwal et al., 1979, Rathee et al., 1982, Khanna et al., 1993, Mahmoud, 1993 and El-Gazzar 1997). Ginger and Nigella sativa oil used as fungicide or fungistatic against twenty fungi including pathogenic and industrial strains (Islam $e t$ al., 1989). Nowadays, Nigella seeds and oil are used in increasing immunity and maintaining good health (Abdel-Aal and Attia, 1993 Hussein et al., 2000). 
This study was undertaken to determine the usefulness of Ginger fed to Nile tilapia fingerlings on its growth and economic performance, body composition and organs indices.

\section{MATERIALS AND METHODS}

\section{Experimental conditions:}

The present study was conducted to investigate the effects dietary supplementation of Ginger extracts as natural growth promoters on growth performance, nutrients utilization, survival rates, whole body composition and economic efficiency of Nile tilapia (Oreochromis niloticus) fingerlings were reared in cages constructed into earthen ponds system. The study was conducted in the fish farm belonging to General Authority of Fish Resources Development (GAFRD) located at El-Hamul city (El-Zawya fish farms), Kafr El-Sheikh Governorate, Egypt.

The main water source of the farm is the drainage canal called Hamdy canal, during the rearing period (16 weeks, 112 days) from $29^{\text {th }}$ June to $18^{\text {th }}$ October 2014 16 weeks (112 days).

\section{Experimental design:}

The feeding trial was conducted in three groups of healthy monosex fingerlings Nile tilapia (O. niloticus) fish in nine $\mathrm{m}^{3}(3 \times 3 \times 1 \mathrm{~m})$ net cages (in triplicate) each contained 432 fish by rate $(5.5 \mathrm{fish} / \mathrm{m} 3)$ were placed into one earthen pond system with a total area each of $525 \mathrm{~m} 2(15 \times 35 \mathrm{~m}$.), with a depth of $1.5 \mathrm{~m}$ and water flow.

Triplicate per treatment were used in this study as following: Group 1 (T1) control: considered as control diets (basal diet without Ginger extracts). Group 2 (T2): $0.5 \%$ Ginger extracts. Group 3 (T3): $1.0 \%$ Ginger extracts.

Net cages were set on wooden stales and attached to wooden structures. The pond was rectangular in shape, well exposed to sunlight, independent completely free from aquatic vegetation, basin conformation and bottom soil type were also similar. The pond has inlet and outlet facilities. The main source of water was drainage. Water inlet was carried out using a water pump $16 \mathrm{HP}$ power. The embankment was well protected.

\section{Construction of cages:}

The frame of the experimental net cages were constructed of wood poles and covered by nylon net.

The mesh size of the net was selected as it required to prevent the fishes from escaping from the cage and to keep water passing easily through the cage. An opening was kept at the top of each cage for supplying feed and handling of the fishes.

\section{Submersion of cages:}

The cages were submerged $15 \mathrm{~cm}$ above of the pond bottom giving a water volume of $1.0 \mathrm{~m}^{3}$. Two vertical and a horizontal wood poles were used to hang each cage. Nylon rope was used to tie the cages to make it float with the help of the wood poles. The cages were located four meters away from the nearest bank of the pond. A wooden made bridge and platform was used to operate the cage.

\section{Ponds preparation:}

Prior to the experiment, ponds were de-watered and aquatic vegetation was cleaned. The dikes of ponds were repaired. Ponds were filled (on day-2) with water. Quicklime (on day-3) was applied to the ponds by spreading methods at the rate of 10 $\mathrm{kg} /$ pond. After one week of lime application the ponds were fertilized with both of urea and TSP each of $1 \mathrm{~kg} /$ pond. Required the TSP and urea were mixed together 
and dissolved in plastic bucket for 10-12 hours then applied to the pond. After 5 days of fertilizer application of Nile tilapia (O. niloticus) fingerlings were stocked in cages. The cages were suspended on the pond surface waters by direct attachment to wooden piers.

\section{Cages management:}

The nets were cleaned regularly during feeding time. The dead fish was removed to keep the environment good for fish. The cages were lifted from water every 3 days to check the net whether had any damage.

\section{Experimental fish:}

Nile Tilapia (Oreochromis niloticus) monosex fingerlings were used in the present study. The experimental fish were purchased from a private fish hatchery at El-Hamoul, Kafr El-Sheikh Governorate, Egypt. The experimental fish was transported early morning to the experimental site in containers.

\section{Stocking of Nile Tilapia fingerlings:}

The fish were kept for acclimatization at the experimental conditions for seven days before the trial began. After the groups were allocated and fish acclimatized on the control diet (without Ginger extracts), fish samples were weighed using a digital scale and measured using a measuring board to obtain the initial samples of the groups. Total of $432 \mathrm{fish}\left(5.5 \mathrm{fish} / \mathrm{m}^{3} \times 9 \mathrm{~m}^{3} /\right.$ cage $\times 50 \mathrm{fish} /$ cage $\mathrm{x}$ triplicate treatment group x 5 alternative dietary source for tilapia) with an mean initial body weight of $10 \pm 0.19 \mathrm{~g} /$ fish were randomly stocked into eighteen $9 \mathrm{~m}^{3}$ net cages. A completely randomized design was adopted, where Three diets were fed to triplicate groups.

Preparation of garlic and onion oil extracts and the experimental diets:

A commercially available garlic and onion oil extracts were used as dietary natural growth promoters tested. The dietary additives were mixed with the basal diet in a fish mill factory (El-Tawheed at El-Reyad city) and pressed in pellets two millimeter in diameter. A commercial fish diet containing $30 \%$ crude protein was used in the present study. The diet was purchased from Manzala fish feed factory. three each experiment, the required concentration 0 (control), $0.5 \%$ and $1 \%$ Ginger extracts were mixed in the basal diet. To prepare the diets, a commercial pellet fish diet was crushed, mixed with the appropriate Ginger extracts concentration and water, and made again in to the pellets, which were allowed to dry for $18 \mathrm{~h}$ at $45 \mathrm{C}$ by air circulation and stored in a dried room during the whole experimental period. Control diet was prepared adding only water. Nile tilapia $(O$. niloticus) fingerlings were fed the experimental diet for 16 weeks in rate of $5 \%$ of the body weight per day, spread across two feeding times (09:00 am and 15:00 pm) for 6 days a week, for 112 days and fish were weighed biweekly. The composition and chemical analysis of the basal diet is illustrated in Table (4).

\section{Sampling of fish and Feeding:}

Fish were sampled weekly (between 07:00 and 10:00 hours) during when the weights (Ohaus portable digital scale (model DIGI DS 671); $\pm 0.1 \mathrm{~g}$ ), standard and total length (measuring board; $\pm 1.0 \mathrm{~mm}$ ) and the number of fish were assessed for each treatment. At least twenty-five live fish in each cage -in-pond were randomly scooped out of each cage unit for their measurements and immediately returned to their respective cages. The cage nets were inspected and cleaned during each sampling. Feeding rate was adjusted weekly. Daily feed consumption (feed given to fish) and mortalities were recorded. Dead fish were replaced immediately with similar size specimens within the first ten days of culture. The amounts of feed in respective fish type were determined through the sampling that was carried out weekly throughout the culture period to monitor growth performance. 


\section{Harvesting of fish:}

At the end of the experiment, water was pumped out of pond and all fish from each experimental cage were harvested, recovered, weighed in kilograms and counted. The individual body weight and total fish weight were taken. The total length of fish was measured as well (Precision $=1 \mathrm{~mm}$ ).

\section{Analytical methods:}

Before and end of the experimental period of 112 days, five whole fish from each of the treatment and control cages were randomly collected using hand net. The captured fish were degutted and cleaned with tap water and sacrificed by a lethal dose of anesthesia (150 mg/L MS- 222), homogenized in a blender, and stored at $-20{ }^{\circ} \mathrm{C}$ for proximate analysis of the carcass composition. Initial body analyses were performed on a pooled sample of 50-gram fingerlings, which was frozen prior to the study. Samples of fish and nutritional composition were collected from several sacks and send for proximate analysis at the Central Laboratory for Aquaculture Research at Kafr El-Sheikh Governorate, Egypt. The proximate composition (moisture, crude protein, crude lipid and ash) of fish body composition have been carried out before and after the experiment according to the methods of (A.O.A.C 2005).

The nutritional composition of the experimental diets ratio of test feeds were analyzed prior to diet formulation. All the ingredients were ground to fine powder before being subjected to proximate analysis (Table 1). The analyses involved the following nutrients: dry matter $(\mathrm{DM})$, crude protein $(\mathrm{CP})$, ether extract $(\mathrm{EE})$, ash, nitrogen free extracts (NFE) and crude fiber (CF). CP was estimated from Kjedahl nitrogen, while EE was quantified as the loss in weight after extraction of the sample with petroleum ether. Ash was determined by combustion dry samples in a muffle furnace at $550{ }^{\circ} \mathrm{C}$ for 12 hours. $\mathrm{CF}$ was determined by a consecutive alkaline acid digestion, which was followed by ashing the dry residue at $550{ }^{\circ} \mathrm{C}$ in a muffle furnace for 12 hours. Carbohydrate as nitrogen-free extract (NFE) was determined by the difference method DM, CP, EE, CF and Ash ALVA, (1983). Each ingredient was homogeneously ground and passed through a 100 u.m sieve. Before diet formulation, the proximate composition of feed was determined (Table 1).

Table 1: Tested fish groups and proximate composition of the test diets.

\begin{tabular}{|c|c|c|c|}
\hline \multirow[b]{2}{*}{$\begin{array}{c}\text { test diets } \\
\text { Chemical composition (\%) As fed basis }\end{array}$} & \multicolumn{3}{|c|}{ Experimental Fish Groups } \\
\hline & $\begin{array}{c}\text { T1 } \\
\text { Control } \\
0.0 \%\end{array}$ & $\begin{array}{l}\text { T2 Ginger } \\
0.5 \% / \mathrm{kg} \text { feed }\end{array}$ & $\begin{array}{l}\text { T3 Ginger } \\
1.0 \% / \mathrm{kg} \text { feed }\end{array}$ \\
\hline Ginger & 0 & 0.5 & 1.0 \\
\hline Dry matter & 90.8 & 90.8 & 90.8 \\
\hline Moisture & 9.2 & 9.2 & 9.2 \\
\hline Crude protein & 30 & 30.80 & 30.97 \\
\hline Crude fat & 3.13 & 3.13 & 3.13 \\
\hline Ash & 15.5 & 15.5 & 15.5 \\
\hline $\mathbf{C F}$ & 8.2 & 8.2 & 8.2 \\
\hline Soluble carbohydrate $^{1}$ & 43.17 & 42.37 & 42.20 \\
\hline Gross energy $(\mathbf{G E})^{2}$ & 362.23 & 377.39 & 377.56 \\
\hline
\end{tabular}

1 Nitrogen-free extracts $(\mathrm{NFE})=100-[\%$ lipid $+\%$ protein $+\%$ Fiber+ $\%$ Ash $]$.

2 Gross energy value was calculated from their chemical composition, Estimated according to Jobling, (1983). As 5.64, 9.44 and $4.11 \mathrm{Kcal} / \mathrm{g}$ for protein, lipid and NFE, respectively.

\section{Pond and water quality parameters management:}

The experimental pond was fertilized fortnight at a rate of $2.0 \mathrm{~kg} \mathrm{~N}$ and 0.250 kg P / feddan with Urea and Triple Super phosphate (TSP) according to Hussein (2001), respectively. Physico-chemical parameters of water in the vicinity of the 
cages were monitored prior to stocking and three times a week thereafter to ensure that they were within the recommended limits for fish growth. Sample collections were made between 8.00 am and 9.00 am on each sampling day and were measured in situ. Key water quality parameters, which included water temperature $\left({ }^{\circ} \mathrm{C}\right), \mathrm{pH}$, dissolved oxygen (DO-mg/l), un-ionized ammonia $\left(\mathrm{NH}_{3}-\mathrm{N}\right)(\mathrm{mg} / \mathrm{l})$, Nitrite $\left(\mathrm{NO}_{2}-\mathrm{N}\right)$ $(\mathrm{mg} / \mathrm{l})$ and Nitrate $\left(\mathrm{NO}_{3}-\mathrm{N}\right)(\mathrm{mg} / \mathrm{l})$ were measured three times a week in the cages experiment. For water quality parameters study, three water samples were collected from each of the cages and outside the cages i.e; from pond in which the cages were set up. The water samples were kept in separate clean white plastic bottles and each was marked properly. Water temperature, conductivity dissolved oxygen, and $\mathrm{pH}$ were analyzed and recorded on the dike of the pond. For each parameter three samples were tested. Water temperature was measured and monitored daily around 09:00 hours and 13:00 hours GMT using a glass Celsius thermometer. DO was measured using model 57 oxygen meter (YSI industries, Yellow Springs, Ohio, 4387, USA), while a glass electrode $\mathrm{pH}$ meter, Hi-9024 microcomputer (Hanna Instruments Ltd., Chicago, IL., USA), was used to take $\mathrm{pH}$ measurements) while un-ionized ammonia $\left(\mathrm{NH}_{3}-\mathrm{N}\right)(\mathrm{mg} / \mathrm{l})$, Nitrite $\left(\mathrm{NO}_{2}-\mathrm{N}\right)(\mathrm{mg} / \mathrm{l})$ and Nitrate $\left(\mathrm{NO}_{3}-\mathrm{N}\right)(\mathrm{mg} / \mathrm{l})$ were determined according to the methods of activity of water soluble components of some common diet vegetables and the effect.

Evaluation of growth performance and feed utilization efficiency:

Fish from each cage was measured individually for weight and length every 7 days and at the end of the 112 days trial. Besides, growth parameters were measured according to standard formulation at the end of the culture period. Final harvesting was made through draining of water by water pump.

Growth performance for each treatment group was determined and feed utilization was calculated as described by Sveier et al. (2000) as follows:

Mean weight gain $=[$ final mean weight $(\mathrm{g})-$ initial mean weight $(\mathrm{g})]$

Where: $\mathrm{W} 1$ and $\mathrm{W} 2$ are the initial mean and final mean fish weight, respectively.

\section{Mean daily weight gain}

This was calculated as $(W f-W i) / \mathrm{t}$ where $W f$ is the final mean weight at harvest $(\mathrm{g}), W i$ is the initial mean weight at stocking and $\mathrm{t}$ is the time in days.

\section{Specific growth rate (SGR)}

The specific growth rate for each treatment group was calculated using the formula:

$\mathrm{SGR}=\mathrm{SGR}=100 \times[(\operatorname{loge} W f-\log e W i)] / \mathrm{t}$

Where, $\log e$ is natural $\log$, Wf is the final mean wet weight $(\mathrm{g}), W i$ is the initial mean wet weight and $t$ is the time in days (Ricker, 1979).

Condition Factor (K) was calculated according to (Begenal and Tesch 1978)

as: $K=100\left(\mathrm{Wt} / \mathrm{L}^{3}\right)$. where $K=$ condition factor, Wt is fish body weight $(\mathrm{g})$, L is total length $(\mathrm{cm})$.

Feed utilization efficiency indices calculated as mentioned by Ballestrazzi et al., (1994) are as follows:

Feed intake $=$ Total feed consumed/No of fish stocked

Food conversion ratio (FCR) was obtained from Castell and Tiews, (1980)

$\mathrm{FCR}=$ dry weight of feed consumed (Feed intake) $(\mathrm{g}) /$ wet weight gain $(\mathrm{g})$.

Protein efficiency ratio (PER \%) = Wet body weight gain (g)/ Crude protein fed (intake)

Where, Protein intake $=(\%$ protein in feed $\mathrm{x}$ total diet consumed $) / 100$.

Protein productive value $($ PPV \%) $=100$ [protein gain $(\mathrm{g}) /$ protein fed $(\mathrm{g})$ ]

Energy utilization $($ EU \%) $=100($ energy gain $(\mathrm{g}) / \mathrm{energy}$ intake $(\mathrm{g})$. 


\section{Blood sample collection:}

At the end of the experiment, three fish were sampled randomly from each cage and were anesthetized with clove solution, and about $4 \mathrm{~mL}$ of blood was drawn from the caudal vein, using a syringe. Then, blood samples were introduced to both heparinized and non-heparinized tubes in order to perform haematological and immunological studies, respectively. Blood sera were obtained by centrifuging blood samples at $3000 \mathrm{rpm}(15,60 \mathrm{~g})$ for $10 \mathrm{~min}$ using a Heraeus Labofuge 400, and the sera were removed with a disposable transfer pipette. And stored at $20 \mathrm{C}$ until analysis for biochemical and immunological studies.

\section{Hematological assays:}

The erythrocyte (RBC) and leukocyte (WBC) counts were determined using a Neubaeur hemocytometer Hemoglobin levels $(\mathrm{Hb})$ were obtained by the cyanomethemoglobin spectrophotometry method.

\section{Biochemical assays:}

Biochemical analysis was performed in the sequence: total protein (Biuret method), albumin (Bromocresol Green method) .

\section{Economic analysis:}

At the end of the experiment, all fish were sold and the prices of fish were attributed to the Egyptian local fish market price in October 2014. Economic analysis was conducted to determine economic returns. The analysis was based on market prices in Egypt for harvested fishes and all other items, which was expressed in Egypt. The following simple equation was used according to (Asaduzzaman et al. 2009).

$R=I-(F C+V C+I i)$ Where, $R=$ net return, $I=$ income from monosex tilapia sale, $F C=$ fixed/common costs, $V C=$ variable costs and $I i=$ interest on inputs

The Benefit-cost ratio, $\mathrm{BCR}$ was calculated as:

$\mathrm{BCR}=$ net benefit (Total net return) / total expenditure (Total input cost)

\section{Statistical analysis:}

The obtained numerical date was statistical analyzed using Spss, (1997) for one-way analysis of variance. When F-Test was significant, least significant difference was calwlated according to Duncan, (1955).

\section{RESULTS AND DISCUSSION}

\section{Water quality parameters:}

Water quality parameters of pond and cages were examined to observe any appreciable changes that might have occurred between pond and cages. The overall mean values of each water quality parameters as recorded from different sampling are presented in Table (2). One-way analysis of variance (ANOVA) was performed on the data to observe whether any difference exists in different sampling or not. Water quality did not vary significantly $(\mathrm{P}>0.05)$ among treatments, both in cages and in ponds over the culture periods.

The physico-chemical parameters as samplings did not vary indicating that the water quality parameters had the same equally affected inside and outside the cages. Water quality in broader sense includes all physical, chemical and biological characteristics of water. The existence, growth, production and wellbeing of aquatic life are mediated through a chain of interacting physical and chemical parameters of water. Moreover, water quality is directly related to the productivity of water body, the growth, production and survival of fish and other aquatic animals. In the present 
study, the mean $( \pm$ SE) values of the water quality parameters for the cages and in pond at selected stations including water temperature, dissolved oxygen, $\mathrm{ph}$.

While, un-ionized ammonia-nitrogen $\left(\mathrm{NH}_{3}-\mathrm{N}\right)(\mathrm{mg} / \mathrm{l})$, Nitrite nitrogen $\left(\mathrm{NO}_{2}-\mathrm{N}\right)$ and nitrate nitrogen $\left(\mathrm{NO}_{3}-\mathrm{N}\right)$ were within the suitable range for fish culture Table (2).

Table 2: Mean value with standard Error $( \pm \mathrm{SE})$ of water quality parameters as recorded from inside of cages and outside of cages (pond) during the experimental period (112 days)

\begin{tabular}{|c|c|c|c|c|}
\hline \multirow{2}{*}{ Water quality parameters } & \multicolumn{3}{|c|}{ Cages (Experimental Fish Groups) } & \multirow{2}{*}{ pond } \\
\hline & Control & Garlic & Onion & \\
\hline Temperature $\left({ }^{\circ} \mathbf{C}\right)$ & $27.8 \pm 0.11$ & $28.1 \pm 0.21$ & $27.9 \pm 0.10$ & $27.10 \pm 0.3$ \\
\hline Dissolved Oxygen (mg/l) & $7.63 \pm 0.16$ & $7.28 \pm 0.11$ & $7.43 \pm 0.14$ & 7. $70 \pm 0.0$ \\
\hline pH (pH unit) & $7.51 \pm 0.51$ & $7.86 \pm 0.71$ & $7.64 \pm 0.54$ & $7.4 \pm 0.0$ \\
\hline $\begin{array}{l}\text { un-ionized ammonia } \\
(\mathrm{mg} / \mathrm{l})\end{array}$ & $0.038 \pm 0.015$ & $0.062 \pm 0.041$ & $0.054 \pm 0.005$ & $0.014 \pm 0.03$ \\
\hline Nitrite $\left(\mathrm{NO}_{2}-\mathrm{N}\right)(\mathrm{mg} / \mathrm{l})$ & $0.07 \pm 0.0022$ & $0.011 \pm 0.003$ & $0.009 \pm 0.0002$ & $0.07 \pm 0.03$ \\
\hline Nitrate $\left(\mathrm{NO}_{3}-\mathrm{N}\right)(\mathrm{mg} / \mathrm{l})$ & $0.017 \pm 0.016$ & $0.038 \pm 0.018$ & $0.032 \pm 0.006$ & $0.021 \pm 0.01$ \\
\hline
\end{tabular}

Non significant level $(\mathrm{P}>0.05)$.

All the water quality parameters analyzed showed no significant difference ( $p>0.05$ ). It was reported that lower than $1 \mathrm{mg} / \mathrm{l}$ of ammonia gas content in pond water was acceptable for pond fish culture. The concentration of un-ionized ammonianitrogen was within acceptable limits, and there was no significant difference of mean ammonia and nitrite among the treatments except for nitrate but did not negatively affect the growth of fish. Fish excrete ammonia directly through gill respiration and, in addition, bacteria break down fish feces and uneaten feed to generate ammonia, nitrite (NO2-) and nitrate (NO3-) from the nitrification process by nitrifying bacteria. This may have resulted from the nitrification process where in Nitrobacter subsequently transformed nitrite to nitrate. A control yielded the lowest nitrate concentration.

All values obtained were within the optimal ranges conducive for aquaculture growth and negatively affect the culture of fish. Moreover, the water quality parameters in different cages were same as in the pond water suggesting that cage culture does not alter the pond environment. Mires (1969) found more or less similar ranges of water quality parameters in their studies. It indicates that cage culture does not affect the pond productivity. Moreover, the feed which is used for cage culture enhanced the productivity of pond that is used as feed by the stocked fish within the pond. All the water quality parameters monitored were within the recommend values for tilapia culture (Thomas \& Michael, 1999).

\section{Growth performance of Nile Tilapia fingerlings fed on different levels}

Tilapia fingerlings fed on different levels of Ginger as natural phyt- additives. Aquaculture requires high quality feeds which should contain not only necessary nutrients but also complementary feed additives to keep organisms healthy, faster growth and environmentally friendly. Data of Table (3) showed the means of weight gain (TWG), daily gain (ADG), specific growth rate (SGR), and condition factor (K) of Nile tilapia fed diets containing different levels of Ginger extract. Maximum growth performance was obtained at inclusion level of $0.5 \%$ Ginger. However, adding up to $1 \%$ Ginger to Nile tilapia diets resulted in an improvement in SGR and ADG compared to the control. While the results of the experiment clearly showed that the diets containing zero and $0.5 \%$ Ginger extract performed slightly lower than the $1 \%$ Ginger extract diet. The specific growth rate, ADG and condition factor of the fish fed on the diets containing $1 \%$ Ginger extract were better than those of zero and $0.5 \%$ Ginger extract diet. 
Table 3: Growth performance of Nile Tilapia fed on the experimental levels of Ginger extract.

\begin{tabular}{llll}
\hline \multicolumn{1}{c}{ Items } & Control & \multicolumn{1}{c}{ Ginger 0.5\% } & \multicolumn{1}{c}{ Ginger 1\% } \\
\hline Initial weight $(\mathbf{I W})(\mathbf{g})$ & $10.33 \pm 0.06 \mathrm{a}$ & $10.28 \pm 0.28 \mathrm{a}$ & $10.19 \pm 0.9 \mathrm{a}$ \\
Final weight $(\mathbf{F W})(\mathbf{g})$ & $141.84 \pm 0.56 \mathrm{c}$ & $185.39 \pm 0.36 \mathrm{~b}$ & $217.33 \pm 0.39 \mathrm{a}$ \\
Initial length (II) (cm) & $7.62 \pm 0.94 \mathrm{a}$ & $7.48 \pm 0.92 \mathrm{a}$ & $7.54 \pm 0.93 \mathrm{a}$ \\
Final length (FI) (cm) & $16.12 \pm 0.05 \mathrm{c}$ & $17.36 \pm 0.6 \mathrm{a}$ & $21.31 \pm 0.06 \mathrm{a}$ \\
Weight gain (WG) (g) & $131.51 \pm 0.61 \mathrm{c}$ & $175.05 \pm 0.53 \mathrm{~b}$ & $210.14 \pm 0.43 \mathrm{a}$ \\
Average Daily gain (ADG) (g) & $1.17 \pm 0.005 \mathrm{c}$ & $1.56 \pm 0.005 \mathrm{~b}$ & $1.88 \pm 0.003 \mathrm{a}$ \\
Specific growth rate (SGR) \% & $2.35 \pm 0.01 \mathrm{c}$ & $2.51 \pm 0.034 \mathrm{~b}$ & $2.76 \pm 0.017 \mathrm{a}$ \\
Condition Factor $(\mathbf{K})$ & $1.94 \pm 0.02 \mathrm{a}$ & $2.41 \pm 0.014 \mathrm{~b}$ & $2.82 \pm 0.17 \mathrm{c}$ \\
\hline
\end{tabular}

$\mathrm{A}, \mathrm{b}, \mathrm{c} .$. : Meaning the same row with different superscripts are significantly different $(\mathrm{P}>0.05)$.

In this study the highest growth performance was observed in fish fed diets containing Ginger, especially on $10 \mathrm{~g}$ Ginger. It agrees with studies results of Diab et al., (2002), Abou-Zeid 2002) and Shalaby et al., (2006). Values of growth performance indices, in the present work, indicate an enhancement in growth for all fish groups fed garlic or onion and Ginger extracts at all inclusion levels compared to the control fish group.

Many authors recorded the positive effects of administrating garlic in diets and Ginger extracts on growth of many fishes including; African catfish, Clarias gariepinus (Agbebi et al., 2013); rainbow trout, Oncorhynchus mykiss (Gabor et al., 2012 and Nya and Austin, 2009); Swordtail, Xiphophorus helleri (Kalyankar et al., 2013) and Nile tilapia, Oreochromis niloticus (Shalaby et al., 2006; Mesalhy et al., 2008; Metwally, 2009; Aly and Mohamed, 2010).

Parallel to the present results, growth enhanc properties of an onion and Ginger extract-based diet showed an increase in body weight gain as recorded by Bello et al., (2012) in African catfish (C. gariepinus) juveniles and also by Apines-Amar et al., (2012) in the brown-marbled grouper, Epinephelus fuscoguttatus.

\section{Feed and protein utilization.}

Date of Table (4) showed that the best feed conversion ratio (FCR), protein efficiently ratio (PER), and protein productive value (PPV) was found when fish were fed the diet containing $0.5 \%$, and $1 \%$ Ginger extract. These results clearly showed that the diets containing 0.5 , and $1 \%$ extract converted feed slightly higher than the control diet. Date of feed conversion ratio (FCR), protein efficiently ratio (PER) and protein productive value (PPV) of the experiment fish clearly showed that the diet containing $1 \%$ Ginger extract was slightly better than those contained zero, and $0.5 \%$ Ginger extract.

Table 4: Effect of a Ginger extract on feed utilization of Nile tilapia monosex.

\begin{tabular}{llll}
\hline \multicolumn{1}{c}{ Items } & Control & \multicolumn{1}{c}{ Ginger 0.5\% } & Ginger 1\% \\
\hline Final weight (FW) (g) & $141.84 \pm 0.56 \mathrm{c}$ & $185.39 \pm 0.36 \mathrm{~b}$ & $217.33 \pm 0.39 \mathrm{a}$ \\
Feed Intake (FI) $(\mathbf{g})$ & $268.67 \pm 0.33 \mathrm{c}$ & $279.19 \pm 0.74 \mathrm{~b}$ & $294.56 \pm 0.55 \mathrm{a}$ \\
Protein Intake (PI) $(\mathbf{g})$ & $67.16 \pm 0.08 \mathrm{c}$ & $70.54 \pm 0.18 \mathrm{~b}$ & $73.64 \pm 0.14 \mathrm{a}$ \\
Feed conversion ratio \% & $1.91 \pm 0.07 \mathrm{a}$ & $1.57 \pm 0.04 \mathrm{~b}$ & $1.36 \pm 0.03 \mathrm{c}$ \\
Protein efficiency ratio (PER) \% & $2.51 \pm 0.01 \mathrm{c}$ & $3.02 \pm 0.01 \mathrm{~b}$ & $3.3 .37 \pm 0.08 \mathrm{a}$ \\
Protein productive value (PPV) \% & $74.62 \pm 0.13 \mathrm{a}$ & $69.20 \pm 0.47 \mathrm{c}$ & $72 . \pm 0.31 \mathrm{~b}$ \\
Protein retained (PR) \% & $49.67 \pm 0.10 \mathrm{~b}$ & $50.02 \pm 0.46 \mathrm{~b}$ & $52.75 \pm 0.16 \mathrm{a}$ \\
Energy retained (ER) (Ke) & $76.70 \pm 0.90 \mathrm{a}$ & $67.71 \pm 0.38 \mathrm{~b}$ & $60.34 \pm 1.83 \mathrm{c}$ \\
Energy utilization $(\mathbf{E U})(\mathbf{K e})$ & $0.84 \pm 0.01 \mathrm{a}$ & $0.68 \pm 0.03 \mathrm{~b}$ & $0.59 \pm 0.08 \mathrm{c}$ \\
\hline
\end{tabular}

$\mathrm{A}, \mathrm{b}, \mathrm{c} . .:$ Meaning the same row with different superscripts are significantly different $(\mathrm{P}>0.05)$.

The results suggest that dietary feed additive promoted the growth of Nile tilapia fingerlings. These results showed that feed additive enhances nutrient utilization, which is reflected in improved weight gain, FCR, PER, PE and SGR. 
Generally, better feed conversion ratio values were obtained in all treatments, but the poorest occurred in control Tables (4). There were significant differences in the FCR among the treatments $(p<0.05)$. Similar results were reported for using two different commercial feed additives for Nile tilapia fingerlings (Abdelhamid and Mohammed, 2008). El-Haroun (2007) also reported that African catfish fingerlings fed on diets supplemented by commercial feed additive Biogen exhibited faster growth than those fed with the control diet. Similarly, in catfish C. gariepinus (Turan and Akyurt, 2005), tilapia O. niloticus (Khattab et al., 2004; Felicitta et al., 2013), olive flounder Paralichthys olivaceus (Cho and Lee, 2012) and shrimp Peneaus indicus (Olmedo Sanchez et al., 2009) feed additives in diets promoted growth and feed efficiency.

\section{Body compositions.}

Values of dry matter (DM), crude protein (CP), ether extract (EE), and ash of the fish body are summarized in Table (5). Crude protein and EE percentages were significantly higher and lower, respectively. When the fish were fed on the control of $0.5 \%$ Ginger extract diets as compared with those fed on $1 \%$ Ginger extract. Y et al., diets included Ginger not altered significantly the ash contents of the whole fish body compared with the control.

Table 5: Means \pm standard errors of proximate chemical analysis ( $\%$ on dry matte basis) of the experimental fish fed on graded levels of Ginger extract.

\begin{tabular}{lllll}
\hline Items & Initial & Control & Ginger 0.5\% & Ginger 1\% \\
\hline Dry matter (DM) & $21.54 \pm 0.23 \mathrm{c}$ & $28.34 \pm 0.26 \mathrm{~b}$ & $29.16 \pm 0.18 \mathrm{a}$ & $29.2 \pm 0.20 \mathrm{a}$ \\
Crude protein & $46.52 \pm 0.42 \mathrm{c}$ & $56.11 \pm 0.11 \mathrm{~b}$ & $59.45 \pm 0.45 \mathrm{~b}$ & $64.17 \pm 0.17 \mathrm{a}$ \\
Crude fat & $20.62 \pm 0.21 \mathrm{~d}$ & $23.79 \pm 0.05 \mathrm{a}$ & $20.64 \pm 0.05 \mathrm{c}$ & $16.12 \pm 0.06 \mathrm{~b}$ \\
Ash & $28.16 \pm 0.32 \mathrm{a}$ & $15.97 \pm 0.12 \mathrm{~b}$ & $15.79 \pm 0.54 \mathrm{~b}$ & $15.56 \pm 0.16 \mathrm{~b}$ \\
NFE & $4.70 \pm 0.02 \mathrm{a}$ & $4.13 \pm 0.15 \mathrm{~b}$ & $4.12 \pm 0.02 \mathrm{~b}$ & $4.15 \pm 0.01 \mathrm{~b}$ \\
\hline
\end{tabular}

A, b, c..: Meaning the same row with different superscripts are significantly different $(\mathrm{P}>0.05)$.

The body composition values obtained in this study were similar to those reported by (Diab et al., 2002, Lara-Flores et al., 2003 and Abdelhamid and Mohamed 2008) using commercial feed additives.

In study of Lee et al., (2012), lipid content in whole body of juvenile sterlet sturgeon fed diet with $0.5 \%$ garlic and Ginger extract was significantly higher $(6.1 \%)$ than that $(5.4 \%)$ of fish fed control.

Increment in crude protein contents was recorded in O. mykiss's body when fed with diets that included 3\% Ginger and garlic (Gabor et al., 2010). In contrast, Cho and Lee (2012) used onion powder at different inclusion levels in the diet of Olive Flounder, $P$. olivaceus and did not record any significant differences in fish protein content between fish groups.

These results agree with those obtained by (Abdelhamid et al., 2002), Khattab et al., (2004), and Shalaby et al., (2006), who showed that inclusion of Biogen and Ginger in the diet increased fish protein content and decreased whole body fat in fish. However, Diab et al., (2002) reported that there were no significant changes in fish body composition caused by different garlic and Ginger levels.

Hematologic and blood chemistry of different levels of Ginger extracts as natural phyto-additives:

The hematological parameters of Nile tilapia (O. niloticus) fingerlings fed on different levels of Ginger extracts as natural phyto-additives are summarized in Table (6). Results showed significant variations $(\mathrm{P}<0.05)$ in Albumin, Total proteins, Hemoglobin, WBC and RBCs values among all inclusion levels or in relation to the control group either in fish fed Ginger extract as feed additives. Results in Table (6) show a gradual elevation in Total proteins, $\mathrm{Hb}, \mathrm{WBC}$ and $\mathrm{RBC}$ content 
accompanying the increment in Ginger inclusion level. The values were found to be significantly higher in $0.5 \%$ and $1 \%$ when compared to the control group. Fish fed Ginger extract at all supplementation levels show a significant $(\mathrm{P}<0.05)$ increase in blood serum biochemical and hematological parameters values of Nile Tilapia $(O$. niloticus) fingerlings comparing with the control group.

Table 6: The blood serum biochemical and hematological parameters of Nile Tilapia (O. niloticus) fed on different levels of Ginger extracts.

\begin{tabular}{llll}
\hline Items & Control & Ginger 0.5\% & Ginger 1\% \\
\hline Albumin g/dl & $1.81 \pm 0.005 \mathrm{c}$ & $2.00 \pm 0.005 \mathrm{~b}$ & $2.23 \pm 0.005 \mathrm{a}$ \\
Total proteins g/dl & $4.10 \pm 0.05 \mathrm{c}$ & $4.62 \pm 0.05 \mathrm{~b}$ & $5.25 \pm 0.05 \mathrm{a}$ \\
Hemoglobin Hb (g/dl) & $7.70 \pm 0.50 \mathrm{c}$ & $8.21 \pm 0.06 \mathrm{~b}$ & $8.80 \pm 0.07 \mathrm{a}$ \\
WBCs $(\mathbf{c m})$ & $36000 \pm 0.57 \mathrm{c}$ & $43000 \pm 0.08 \mathrm{~b}$ & $51000 \pm 0.06 \mathrm{a}$ \\
RBCs mill/cm & $2.01 \pm 07 \mathrm{c}$ & $2.47 \pm 0.20 \mathrm{~b}$ & $2.56 \pm 0.01 \mathrm{a}$ \\
\hline
\end{tabular}

Data expressed as mean \pm SE. Values in the same column sharing the same superscript letter are not significantly different $(\mathrm{P}>0.05)$.

Fish fed Garlic or onion extracts were separately compared with fish fed control diet.

The present study demonstrated that administration of Ginger extract induced a considerable increase in some measured blood parameters ( $\mathrm{Hb}, \mathrm{RBCs}$ and WBCs) in treated fish and this result coincided with Kalyankar et al.,(2013) who revealed that administration of $1.5 \%$ garlic and Ginger in Swordtail, X. Helleri diet induced significant increases in all blood parameters (RBCs, WBCs, Hb). Ndong and Fall (2011) recorded that total leukocyte count (WBCs) increased significantly by $23.62 \%$ and $43.67 \%$ for hybrid tilapia $(O$. niloticus $\times$ $O$. Blood tests reveal the body condition of fish long before the visible manifestation of disease (Musa and Omoregie, 1999). Positive changes in the values of Albumin, total proteins, hemoglobin, WBC and RBCs in fish fed the $1 \%$ garlic and Ginger diet indicate increased protection rendered by A. sativum.

Albumin, total proteins, hemoglobin, WBC and RBCs in fish fed diets containing Ginger garlic and onion significantly differed from the control in treated fish, in agreement with the results of (Kumar and Reddy 1999; Hussein et al., 2001; Martinz et al., 2002; Thomson \& Ali 2003 and Shalaby et al., 2006). These values were highest in fish fed the $1 \%$ Ginger diet, followed by those fed the $1 \%$ onion diet. aureus) fed with $1 \%$ garlic and Ginger supplemented diet after 2 and 4 weeks, respectively.

\section{Economic efficiency}

* The economical evaluation of results was carried out according to market prices in 2014 in LE.

O. niloticus $=100 / 1000$ fingerlings. Triple super phosphate $=\mathrm{LE} 1200 / 1000 \mathrm{~kg}$.

Urea $=$ LE 1650/1000 kg. Manure $=$ LE 610/ $1000 \mathrm{~kg}$.

Fish feed $(25 \%$ protein $)=$ LE $3900 / 1000 \mathrm{Kg}$. fish fed $(3 \%$ protein $)=\mathrm{LE}$ $46000 / 1000 \mathrm{~kg}$

Averages of total variable costs (LE/ Treatment); Fixed costs (LE/ Treatment); total operating costs (variable \& fixed); total return (LE); net return (LE/ Treatment) and the $\%$ of the smallest value of net return as percentage to the control group one presented in Table (7). The economic efficiency was calculated on the total return (LE); net return (LE/ Treatment) and the \% of the smallest value of net return, thus other costs were equal for the experimental groups. Results of the same table indicated that incorporation of Ginger extracts as feed additives in diets of Nile Tilapia (O. niloticus) fingerlings increased the costs of one $\mathrm{kg}$ of diet and the increase was more pronounced at higher incorporation level (1\%) compared to the lower one 
$(0.5 \%)$. Results of Table (7) revealed that net return (LE/ Treatment) for the control $(0.5 \%)$; and (1.0\% Ginger) groups were 116; 193 and 185.5, respectively, which indicate incorporation of Ginger extracts to growing Nile tilapia diets increased the \% of the smallest value of net return by 166 , and 185.5 percent compare to the control group.

Table 7: Effect of Ginger extracts on economic of Nile Tilapia (O. niloticus) fingerlings:

\begin{tabular}{|c|c|c|c|}
\hline Items & Control & Ginger $0.5 \%$ & Ginger $1.0 \%$ \\
\hline \multicolumn{4}{|c|}{ A- Variable costs (LE/Treatment) } \\
\hline a. Nile Tilapia fingerlings & 30 & 30 & 30 \\
\hline b. Feeds & 322 & 348 & 353.5 \\
\hline c. Ginger oil & - & 62 & 106 \\
\hline d. Poutry manure & 15 & 15 & 15 \\
\hline e. Triple supper phosphate & 5 & 5 & 5 \\
\hline f. Urea & 1.5 & 1.5 & 1.5 \\
\hline Total variable costs $(\mathrm{LE})$ & 373.5 & 461.5 & 511 \\
\hline \multicolumn{4}{|c|}{ B- Fixed costs (LE/Treatment) } \\
\hline a. Depreciation (materials and others) $10 \%$ & 37.5 & 45 & 51 \\
\hline b. Transport & 20 & 20 & 20 \\
\hline Total fixed costs (LE) & 57.5 & 65 & 71 \\
\hline Total operating costs (variable $\&$ fixed) & 431 & 426.5 & 582 \\
\hline \multicolumn{4}{|c|}{ Returns } \\
\hline Total return $(\mathrm{LE}) *$ & 547 & 712 & 775 \\
\hline Net return (LE/Treatment) & 116 & 185.5 & 193 \\
\hline$\%$ of the smallest value of net return & 100 & $\% 159$ & $\% 166$ \\
\hline
\end{tabular}

The results indicated that Ginger extracts supplementation increased the costs of one $\mathrm{kg}$ of diet but this was compensated through the better gain in weight which resulted in reduction of gain costs. In general results of Table (7) indicated that incorporation of garlic and Ginger at $1 \%$ level to growing Nile tilapia diets resulted in the highest reduction in gain costs due to diet. However, the nutritional effects of the feed additive level used must be carefully determined and taken into account when selecting an economic inclusion level. Therefore, the recommended level of the inclusion is $1 \%$ Ginger extracts feed and this choice is based on the nutritional parameters and economic analysis.

\section{REFERENCES}

A. O. A. C. (2005). Official methods of analysis of AOAC International. AOAC International.

Abou-zeid S.M. (2002). The effect of some medical plants on reproductive and productive performance of Nile tilapia fish. Biosci. Rep., Fac. Agriculture Cairo Univ., 212.

Abdel-All, E. S. M. (1993). Characterization of black cumin (Nigella sativa) seeds. 2Proteins. Alexandria Scientific Exchange, 14, 483-496.

Abd Elmonem, A., Shalaby, S. M. M. and El-Dakar, A. Y. (2002). Response of red tilapia to different levels of some medicinal plants by-products black seed and roquette seed meals. In Proceedings of the First Conference of Egyptian Aquacultural Society, pp. 247-280.

Abdelhamid, A. M., Khalil, F. F., El-Barbary, M. I., Zaki, V. H. and Husien, H. S. (2002). Feeding Nile tilapia on biogen to detoxify aflatoxin diet. In Annual Scientific Conference of Animal and Fish Production 1. Proceedings Mansoura University (pp. 207-230). 
Abdelhamid, A. M. (2003a). Horses breeding monshaat almaaref alexandria deposit no. $20822 / 2002$.

Abdelhamid, A. M., Abd El-Khalil, A. E., Mostafa, M. A. A., Gomaah, S. A. A. and Khalil, F. F. (2004). Effect of using betafin and/or Biopolym as natural additives in producing nile tilapia fish in poly-culture semi-intensive system in earthen ponds. J. Agric. Sci. Mansoura Univ., 29: 3149-3162.

Abdelhamid, A.M., F. F. Abou Ammou, A.E. Abdel-Khalek, M.E. Ahmed, E.I. Shehata and G.A. Maged (2004). Effect of dietary supplementation with chamomile flowers on carcass characteristics and histology of some organs in Rahmani sheep. J. Agric. Sci. Mansoura Univ., 29: 6119.

Abdelhamid, A. M., Salem, M. F. I. and Tolan, A. E. (2004). Evaluation of sesame meal as a dietary protein source for Nile tilapia (Oreochromis niloticus) fingerlings. J. Agric. Sci. Mansoura Univ, 29: 6887-6897.

Abdelhamid, A. M., Ahmed, A. A. and El-Meleigy, K. M. (2004). An attempt to alleviate the histological alterations of some internal organs of rats fed on aflatoxin contaminated diets. J. Agric. Sci. Mansoura Univ., 29: 2355-2370.

Abdelhamid, A. and Mohamed, K. A. (2008). Effect of using probiotic as growth promoters in commercial diets for mono sex Nile tilapia (Oreochromis niloticus) fingerlings. In $8^{\text {th }}$ International Symposium on Tilapia in aquaculture, Cairo, Egypt, pp. 12-14.

Agarwal, R., Kharya, M. D. and Shrivastava, R. (1979). Antimicrobial \& anthelmintic activities of the essential oil of Nigella sativa Linn. Indian Journal of Experimental Biology, 17(11): 1264.

Apines-Amar, M. J. S., Amar, E. C., Faisan Jr, J. P., Pakingking Jr, R. V. and Satoh, S. (2012). Dietary onion and ginger enhance growth, hemato-immunological responses, and disease resistance in brown-marbled grouper, Epinephelus fuscoguttatus. Aquaculture, Aquarium, Conservation and Legislation, 5(4): 231-239.

ALVA. (1983). Österreichisches Methodenbuch für die Untersuchung von Futtermitteln, Futterzusatzstoffen und Schadstoffen. Arbeitsgemeinschaft landwirtschaftlicher Versuchsanstalten, Irdning, Austria.

Asaduzzaman, M., Lavasani, S., Rahman, M., Zhang, S., Braun, O. Ö., Jeppsson, B. and Thorlacius, H. (2009). Platelets support pulmonary recruitment of neutrophils in abdominal sepsis. Critical Care Medicine, 37(4): 1389-1396.

Aly, S. M. and Mohamed, M. F. (2010). Echinacea purpurea and Allium sativum as immunostimulants in fish culture using Nile tilapia (Oreochromis niloticus). Journal of Animal Physiology and Animal Nutrition, 94(5): e31-e39.

Ballestrazzi, R., Lanari, D., D'agaro, E. and Mion, A. (1994). The effect of dietary protein level and source on growth, body composition, total ammonia and reactive phosphate excretion of growing sea bass (Dicentrarchus labrax). Aquaculture, 127(2-3): 197-206.

Begenal, T. and Tesch, F. W. (1978). Age and Growth. Method for assessment of fish production in freshwater.(ed. Bagenal T.), IBP Hand book.

Bello, O. S., Emikpe, B. O., Olaifa, F. E., Bello, O., Emikpe, B. and Olaifa, F. (2012). The body weight changes and gut morphometry of Clarias gariepinus juveniles on feeds supplemented with walnut (Tetracarpidium conophorum) leaf and onion (Allium cepa) Bulb residues. Int. j. morphol, 30(1): 253-257.

Castell, J. D. and Tiews, K. (1980). Report of the EIFAC, IUNS and ICES Working Group on Standardization of Methodology in Fish Nutrition Research, Hamburg, Federal Republic of Germany, 21-23. 
Cho, S. H. and Lee, S. M. (2012). Onion powder in the diet of the olive flounder, Paralichthys olivaceus: effects on the growth, body composition, and lysozyme activity. Journal of the World Aquaculture Society, 43(1): 30-38.

Duncan, D. B. (1955). Multiple range and multiple F tests. Biometrics, 11(1): 1-42.

Diab, A. S., El-Nagar, G. O. and Abd-El-Hady, Y. M. (2002). Evaluation of Nigella sativa L (black seeds; baraka), Allium sativum (garlic) and biogen as feed additives on growth performance and immunostimulants of $O$. niloticus fingerlings. Suez Canal Vet. Med. J., 745-775.

El-Fatatry, H. M. (1975). Isolation and structure assignment of an antimicrobial principle from the volatile oil of Nigella sativa L. seeds. Die Pharmazie, 30(2): 109-111.

El-Dakar, A. Y., Shalaby, S. M. M., Abd Elmonem, A. I. and Wahbi, O. M. (2004). Enhancement of performance using fennel seeds meal as feed additive for Nile tilapia Oreochromis niloticus. J. Egypt. Acad. Soc. Environ. Dev. (B. Aquacult.), 5: 43-67.

El-Gazzar, U. M. B. (1997). Biochemical studies on vit. E deficiency in rats (Doctoral dissertation, M. Sc. Thesis Presented to Fac. Vet. Med., Alexandria Univ).

El-Haroun, E. R. (2007). Improved growth rate and feed utilization in farmed African catfish Clarias gariepinus (Burchell 1822) through a growth promoter Biogen ${ }^{\circledR}$ supplementation. Journal of fisheries and Aquatic science, 2(5): 319-327.

El-Katcha, M. I. (1990). Effect of linseed oil and vitamin $E$ in diets on performance and egg quality of hyaline layer hens. Bull. Zoo., 39: 359-372.

Felicitta, J., Arti Manju, R., Ronald, J., Sakthika, T., Nagarajan, R. and Chelladurai, G. (2013). Effect of different concentrations of somephytoadditives (Allium sativa and Allium cepa) on growth, survival and hematological parameters in tilapia (Oreochromis mossambicus) juveniles. The Israeli Journal of Aquaculture-Bamidgeh, 64, 8p.

Gabor, E. F., Şara, A. and Barbu, A. (2010). The effects of some phytoadditives on growth, health and meat quality on different species of fish. Scientific Papers Animal Science and Biotechnologies, 43(1): 61-65.

Hussein, S. Y., Mekkawy, I. A. A., Moktar, Z. Z. and Mubarak, M. (2000). Protective effect of Nigella sativa seed against aflatoxicosis in Oreochromis niloticus. In Proc. Conf. Mycotoxins and Dioxins and the Environment, Bydgoszcz, pp: 25-27.

Hussein, S. A., Abd-el-Maksoud, H. and Azab, M. E. (2001). Certain biochemical effect of garlic oil on normal and experimentally induced hyperlipidemia in male albino rats. In International Scientific Conference, 2: 103-129.

Islam, S. K., Ahsan, M., Hassan, C. M. and Malek, M. A. (1989). Antifungal activities of the oils of Nigella sativa seeds. Pakistan Journal of pharmaceutical Sciences, 2(1): 25-28.

Rathee, P. S. (1982). Antimicrobial activity of essential oil, fixed oil and unsaponifiable matter of (Nigella sativa L.). Indian Journal of Pharmacological Science, 44: 8-10.

Kalyankar, A. D., Gupta, R. K., Bansal, N., Sabhlok, V. P., and Singh, D. (2013). Effect of garlic (Allium Sativum) against Aeromonas hydrophila and health management of Swordtail, Xiphophorus Helleri. Journal of Environmental Science and Sustainability, 1: 41-48.

Khattab, Y. A., Shalaby, A. M., Sharaf, S. M., El-Marakby, H. I and Rizk Alla, E. H. (2004). The physiological changes and growth performance of the Nile tilapia 
Oreochromis niloticus after feeding with Biogen as growth promoter. Egypt. J. Aquat. Biol. \& Fish., 8:145-158.

Khanna, T., Zaidi, F. A., and Dandiya, P. C. (1993). CNS and analgesic studies on Nigella sativa. FITOTERAPIA-MILANO, 64: 407-407.

Kumar, G. R., and Reddy, K. P. (1999). Reduced nociceptive responses in mice with alloxan induced hyperglycemia after garlic (Allium sativum Linn.) treatment. Indian J. Exp. Biol., 37:662-666.

Lara-Flores M, Olvera-Novoa MA, Guzman-Mendez BE and López-Madrid W. (2003). Use of the bacteria Streptococcus faecium and Lactobacillus acidophilus, and the yeast Saccharomyces cerevisiae as growth promoters in Nile tilapia (Oreochromis niloticus). Aquaculture, 216: 193-201.

Lee, D. H., Ra, C. S., Song, Y. H., Sung, K. I. and Kim, J. D. (2012). Effects of dietary garlic extract on growth, feed utilization and whole body composition of juvenile sterlet sturgeon (Acipenser ruthenus). Asian-Australasian journal of animal sciences, 25(4): 577-583.

Mahmoud, H. M. A. (1993). Inhibitory action of black cummin (Nigella sativa) against Listeria monocytogenes. Alexandria Journal of Agricultural Research.

Martins, M. L., Moraes, F. R., Miyazaki, D. M. Y., Brum, C. D., Onaka, E. M., Fenerick, J. J. and Bozzo, F. R. (2002). Alternative treatment for Anacanthorus penilabiatus (Monogenea: Dactylogyridae) infection in cultivated pacu, Piaractus mesopotamicus (Osteichthyes: Characidae) in Brazil and its haematological effects. Parasite, 9(2): 175-180.

Mesalhy, S., Abdel atti, N. M. and Mohamed, M. F. (2008). Effect of garlic on the survival, growth, resistance and quality of (Oreochromis niloticus), International Symposium an tilapia Aquaculture.

Metwally, M. A. A. (2009). Effects of garlic (Allium sativum) on some antioxidant activities in Tilapia nilotica (Oreochromis niloticus). World Journal of Fish and Marine Sciences, 1(1): 56-64.

Mires, D. (1969). Mixed culture of tilapia with carp and gray mullet in Ein Hamifratz fish ponds. Bamidgeh, 21(1): 25-32.

Musa, S. O. and Omoregie, E. (1999). Haematological changes in the mudfish, Clarias gariepinus (Burchell) exposed to malachite green. Journal of Aquatic Sciences, 14(1): 37-42.

Ndong, D. and Fall, J. (2011). The effect of garlic (Allium sativum) on growth and immune responses of hybrid tilapia (Oreochromis niloticus x Oreochromis aureus). Journal of Clinical Immnunology and Immunopathology Research, 3(1): 1-9.

Olmedo Sanchez J. A., Curiel Flores, A. and Orozco J. R. (2009). The effect of a herbal growth promoter feed additive on shrimp performance. Res. J. Biol. Sci. 4: 1022- 1024. on long term feeding to normal rats. Experientia, 30: 468-470.

Sveier, H., Raae, A. J. and Lied, E. (2000). Growth and protein turnover in Atlantic salmon (Salmo salar L.); the effect of dietary protein level and protein particle size. Aquaculture, 185(1): 101-120.

SPSS. (1997). Inc. SPSS Base 10.0 for Windows User's Guide. SPSS Inc. Chicago, IL, USA.

Shalaby, S. M. M., Abd Elmonem, A. I. and El-Dakar, A. Y. (2003). Enhancement of growth performance, feed and nutrient utilization of Nile tilapia (Oreochromis niloticus), using of licorice roots (Erksous) as a feed attractive. J. Egypt. Acad. Soc. Environ. Develop.(B-Aquaculture), 4(4): 119-142. 
Shalaby, A. M., Khattab, Y. A. and Abdel Rahman, A. M. (2006). Effects of Garlic (Allium sativum) and chloramphenicol on growth performance, physiological parameters and survival of Nile tilapia (Oreochromis niloticus). Journal of Venomous Animals and Toxins including Tropical Diseases, 12(2): 172-201.

Thomson, M. and Ali, M. (2003). Garlic [Allium sativum]: a review of its potential use as an anti-cancer agent. Current cancer drug targets, 3(1): 67-81.

Turan, F. and Akyurt, I. (2005). Effects of red clover extract on growth performance and body composition of African catfish Clarias gariepinus. Fisheries Science, 71(3): 618-620. 